\title{
A Survey of Grammar Instruction from Scholastic Perspective
}

\author{
Yanghua Peng ${ }^{1}$ \\ ${ }^{1}$ School of Foreign Languages, Chengdu College of Arts and Sciences, Chengdu Sichuan, China \\ Correspondence: Yanghua Peng, 888 Minxing Road, Chenghua District Chengdu City, Sichuan Province, China. \\ Tel: 13608219183. E-mail: pengls@126.com
}

$\begin{aligned} & \text { Received: February 23, } 2017 \\ & \text { Accepted: April 10, } 2017 \quad \text { Online Published: April 12, } 2017 \\ & \text { doi: 10.5539/elt.v10n5p76 }\end{aligned}$ URL: http://doi.org/10.5539/elt.v10n5p76

\begin{abstract}
The study of grammar has been paid much attention and the grammar instruction becomes an emphasis and key problem in English language teaching and learning. How to instruct students grammar appropriately becomes controversial for some English teachers increasingly. Some linguistics, theorists and teachers hold that the grammar instruction should be taught traditionally and normally. There should be a standard in classroom instruction. However, others argue that grammar instruction should be approached scholastically, especially in cultural or religious practice since scholastic grammar is of great essence in language itself. On the basis of the theories of second language teaching and learning and acquisition and the viewpoints of Otto. Jespersen and H. Poutsma about scholastic grammar, this paper conducts a survey of grammar instruction at colleges and universities and analyzes the current situation of grammar instruction from scholastic perspective and finds that it is necessary to reconsider the role of grammar instruction and enhance its importance in English teaching and learning. Finally, the paper ends with a conclusion about the deficit of scholastic grammar at colleges and universities and some implications of grammar instruction in the real English language teaching and learning. The survey put forward a basis and reference for Chinese education system especially for liberal education and humanistic quality.
\end{abstract}

Keywords: survey, grammar instruction, scholastic grammar

\section{Introduction}

As we know grammar plays a very important role in language teaching, learning and acquiring. There has been a hot debate on how to instruct grammar in the academic circles. In other words, many teachers at colleges and universities have been trapped in the instruction of grammar. It is traditionally believed that grammar is traditional or school grammar, which prescribes rules of "correctness". It is roughly referred to the general approach thus traditionally formed to the study of language over the years. There is some absolute standard of correctness concerning language use which linguistics or school teachers should view as their duty to maintain. Therefore, theorists and teachers point out that school grammar is fundamental in English language teaching. However, some never believe that scholastic grammar is never a necessary part of foreign language teaching since scholastic grammar differs from traditional grammar in that it is human approach to grammar. What is the role of grammar instruction in language teaching and learning and how to instruct grammar appropriately? The grammar translation approach, the cognitive approach, the communicative approach and audio-lingual approach all believe that the role of grammar should play with slight variations in language teaching. What's the real condition of grammar instruction in China?

In China English teaching and learning becomes increasingly more and more important today. As all we know that the importance of grammar can't be neglected in English language teaching and learning. Without learning the grammar of a language, it is hard to produce grammatically acceptable utterances in writing or communication. This is especially applicable to second language learners; as most of them have to acquire the second language in classroom. The study of grammar has been received much concern at home and abroad and grammar instruction is becoming a hot potato.

Chomsky put forward: "A grammar can be regarded as a theory of a language; it is descriptively adequate to the extent that it correctly describes the intrinsic competence of idealized native speaker (Chomsky, 1966)." Harmer claims that the grasp of grammar is essential for any language user (Harmer, 1983). Alexander argues that the ultimate source of accuracy in any language is grammar. "Grammar plays a very supportive role and we can say 
that it is a shortcut to language acquisition (Alexander, 2000)." Furthermore, from Otto Jesperson's point of view, as far as grammar is concerned, it is the art technique of writing, which is a real reflection of rational thinking, noble character and vital soul of a nation. There is cultural wisdom of a nation which underlies grammar.

Since grammar is the essence of language, the instruction of grammar becomes a corresponding key in English language teaching and learning. This paper will analyze the real condition of the grammar instruction in colleges and universities from scholastic perspective by selecting 10 young English teachers at colleges and universities for an in-depth interview.

\section{Methods}

The author conducts the survey by interviewing the subjects. The author's friends or former classmates are interviewees as subjects and they know and trust each other. The subjects have been informed of the study objective and their real names omission, so the result of the interview in the survey is countable in some way. There are 10 subjects in this survey. The subjects are young college English teachers under 40 working in ten different colleges varying from key university to vocational college (Table 1).

Table 1. Background of subjects

\begin{tabular}{lllll}
\hline Number & Degree & Title & Years at college & Working unit \\
\hline 1 & Post doctorate & vice professor & 8 & National Normal U \\
2 & Post doctorate & vice professor & 10 & Provincial Multiversity \\
3 & Post doctorate & vice professor & 3 & Foreign Language Studies U \\
4 & Doctorate & lecturer & 12 & Provincial Normal U \\
5 & Doctorate & lecturer & 8 & National U of Technology \\
6 & Doctor & lecturer & 11 & U for Nationalities \\
7 & Doctor & lecturer & 19 & Normal U \\
8 & Master & teaching assistant & 18 & Multiversity \\
9 & Master & teaching assistant & 3 & Foreign language studies U \\
10 & Master & teaching assistant & 2 & U of technology \\
\hline
\end{tabular}

Note. U= university.

In order to get a comparatively reliable feedback, the interviewer tries to make the interviewees feel quite free and comfortable as they chat with their friends without any stress. At the same time the interviewer has prepared a summary of the interview, such as background information of the interviewees, professional training, and teaching experience and so on. What they chatted has been transferred and they are permitted to ask any questions to ensure the authenticity and reliability.

The interview goes one by one, and each one last from 40 to 100 minutes. Totally the interviewing hour is 9.5 hours. With the permission of the interviewees, the interviewer recorded what they said in the overall process. And then their talks have been transformed into166208 text words.

In the survey, the grounded theory methods (GTM), developed by Barney Glaser and Anselm Strauss, are applied to deal with the codes. Firstly, the data is pretreated while interviewing is proceeding. The interviewers have been numbered for the sake of the data management. Codes and key words in GTM are categorized and analyzed.

\section{Result}

As a result of the survey, the findings can be categorized into three types. Firstly, scholastic grammar is neglected totally and traditional grammar is dominated in English language teaching; secondly, scholastic grammar is mentioned sometimes but traditional grammar gets more preference; thirdly, scholastic grammar is dominated and traditional grammar is despised. 


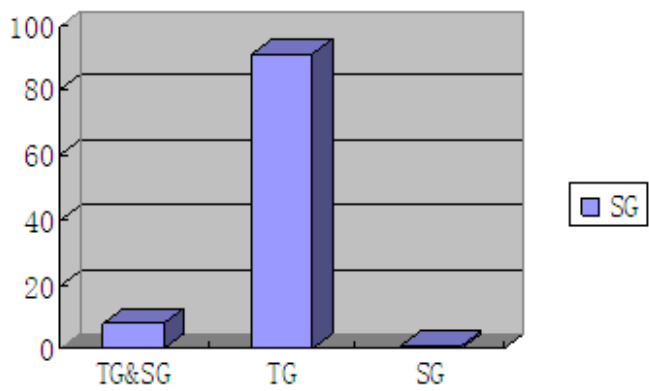

Figure1. Proportion of the scholastic grammar instruction

Note. $\mathrm{S}=$ Scholastic; $\mathrm{T}=$ traditional $\mathrm{G}=$ Grammar.

Just as mentioned previously, the traditional prescriptive grammar aims to lay down rules for "correct and standard" behavior in using language. Or to put it another way, the grammar instruction to some extent is only to be found for grammar's own sake. What's worse, some English teachers are not quite clear about grammar itself because they are taught grammar in the same way of reciting the grammatical rules when they are students. Mostly, they employ the grammar-translation methods. In this method, every unit is devised around the focal point of grammar. The main activities in the classroom are oral translation of the texts into the target language. Grammatical rules are obtained through repeated practice of translation. Grammar-translation method in traditional grammar emphasizes too much the structure of the language as an object of study without any thought about the language itself and its development. The method causes students who had spent years studying English could probably read quite difficult literary texts, but they are totally incapable of ordering a cup of tea in a real practice. It seems that the learners have learned a lot of knowledge but actually this is so superficial that it is far from what learners want. Language is never something dead. It is not sufficient for students to remember the grammatical rules or even produce grammatical sentences; they must know when, why and how to use them.

\section{Discussion}

For most of the Chinese learners, their English study is subjected to plenty of constraints and obstacles. They don't acquire language in the same way as they acquire their mother tongue unless there are exposed to English circumstances. In short, the cross-cultural gap is in charge of the problem. In order to know the English language well, English language learners are asked to do lots of exercises related to traditional grammar. To their surprise, learners find, on not rare occasions, derivations from the regular rules. More interesting is that some English teachers would like to say that it is the habitual usage of foreigners. It is, actually, a desecration of grammar, a presentation of utter irresponsibility. Traditional grammar is just to tell learners what is what and learners are required to do as they are required. It is so prescriptive, arbitrary and rough that even learner can recite some rigid grammatical rules and produce some similar sentences for a while, they still get nowhere for understanding the connotation and actual usage of the very rules.

As contrast to traditional grammar is the "revolutionary" human approach to grammar, scholastic grammar. Louis Hjelmslev once affirms that language is not external accompaniment but it lies deeply in the mind of man, a wealth of memories inherited by the individual and the tribe. So inextricably has language grown inside personality, home, nation, mankind and the life itself that it may be asked whether language is a mere reflection. The same is true of grammar itself. Grammar also can be considered as a distinctive mark of home and nation and nation's patent of nobility. Essentially, grammar was to contribute to a characterization of a nation, conceived as a super-individual social institution. For this reason, scholastic grammar rooted deeply in human society can explain the fluctuating and changing phenomenon while traditional grammar, a disconnected, external facet of grammar itself can not do.

Questions will be asked here: Why is the probably incorrect teaching methods so popular at colleges and universities? How does this phenomenon happen?

The poor and innocent college instructors should be responsible for it because they are taught recitation of the grammatically dead rules and doing repetitively simulative exercises while learning English in school or at colleges. Not being familiar with the history and usage of English language, most of the students learn English as a must for good grades to go to a good college or university. What they can do is to do the exercise right. Even in 
their eyes, there is no necessity to know the reason why it occurs and what scholastic grammar is. When they become teachers, they keep to the traditional teaching methods and pass down from generation to generation. This is the current situation. Here are examples:

A) The flood destroyed the houses last night.

B) The houses were destroyed by the flood last night.

The two sentences have the same meaning in the traditional grammar. A single line between them is that sentence A) is in active voice and sentence B) is in passive one. However, there are many differences between them in scholastic grammar. Besides the active and passive voice, there are more important things here. The fresh information in sentence A) is the houses while the flood in sentence B) respectively, which results in different illocutionary points i.e. what was destroyed last night? and what destroyed the houses last night? In other words, the fresh information imparted to the two sentences is distinctive enough to differentiate the intended meaning of the speaker. In addition, the relatively superior importance and consequent emphasis are quite different when the two are contrasted. Therefore, sentence A) and B), actually, are not the same. Just as a famous saying goes "Only what has been understood can be called real knowledge and such real knowledge can be used appropriately". Then only through understanding the scholastic grammar rooted in culture of society can English language learners at colleges and universities get a better appreciation of language. And this is also accordant with college students' interests and hobbies psychologically.

Besides, based on Immanuel Kant's ideas of cognition of human being, there are three stages: perception, understanding and reasoning. Obviously, the majority of the college students are above the first stage. Young people tend to be curious about not only the result what but also the process how and the reason why. They dislike being ordered to follow something which they absolutely do not know. Naturally, English grammar is not an exception for them. Scholastic grammar is, therefore, much more sufficient than traditional grammar in the process of language learning. In addition, along with the rapid development of science and technology, great changes have taken place in the world. Everything is changing quickly, so is grammar. Grammar does not mean a static concept or a series of rules but means something more pliable; it is, as it were, animate or articulated as human being.

Eventually, it has been advocated strongly to develop the liberal education and enhance the humanistic quality while reforming the education system. In order to meet the challenge of the coming knowledge economy, higher pedagogical education should regulate its managing procedures, reform its curriculum provision and restructure a corresponding mode of its own.

\section{Conclusion}

As a result of the discussion, it has been found that the deficit of scholastic grammar instruction exists at colleges and universities. Scholastic grammar should be considered as a key position in college English teaching and learning while emphasizing the liberal education and enhancing humanistic quality in China. Both teachers and students should try to learn more about English history and its development dynamically. And always view language as being dynamic and approach English language humanly. Whichever teaching methods, as mentioned previously, grammar-translation method or audio-visual and audio-lingual or communicative approach are employed, scholastic grammar should has got more concern in grammar construction. The system of courses offering also changes as the change of the language itself. This is not to minimize the value of all these grammatical rules in traditional grammar and all these efforts, but to point out the danger that in our zealous haste towards the goal of getting a better score in examinations we may overlook grammar itself. Grammar instruction does not simply mean teaching students to recite the grammatical rules which is a commonplace in traditional grammar; moreover, it provides a key to the cognitive system of a nation. Departed from human culture, pure grammar does not exist in life. The survey provides some implications of grammar instruction in the real English language teaching and learning. The structure of grammar can be embedded in meaningful, communicative contexts while instructing grammar. When learners can get a better understanding and communication if they know the meaning context and become more interested in learning how to grammatically produce their ideas. Also, grammar should be viewed as a dynamic process for both teachers and students and it should be approached cognitively in accordance with the human society. In the process of language learning, learners intend to be able to produce and understand contextually appropriate sentences. Yet, the present condition based on the survey in language teaching and learning is far from being good and the grammar instruction has a long way to go in China. What is required, in the long run, is to reconsider the position of grammar and establish a real and rational attitude towards grammar. In consequence, it is quite clear and uncontroversial to say that more attention should be paid to scholastic grammar in the future, as it is much more 
fundamental than traditional grammar in modern classroom. Correspondingly, the effective grammar instruction should be consciously applied in actual language teaching and learning. It should be treated as aids and resources not only of function that speaker intends to produce his utterance but also of meaning that aims to serve the understanding of people in linguistic context and in social context. It is also up to the Chinese education system especially for liberal education and humanistic quality, which is significant to both languages learning and teaching.

\section{Acknowledgements}

My hearty thanks will go to all those who have given much help to me. First, sincere thanks and gratitude goes to Professor Weimin Wang who deserves a great deal of thanks for his help and encouragement. Appreciation is also expressed to him for always being kind, understanding, and helpful during the undertaking of the work. Their timely feedback allowed me to move through this process with confidence. I can only hope to offer future students mentorship and guidance as they have to me. Finally, I owe a lot to my family for their constant support and love.

\section{References}

Alexander, L. G. (1988). Longman English grammar. Harlow: Longman.

Bolinger, D. D. (1981). Sears. Aspects of language. New York: Harcourt Brace Jovanovich.

Brown, H. D. (1994). Teaching Grammar and Vocabulary. N.J.: Prentice Hall Regents.

Canale, M., \& Swain, M. (1980). Theoretical bases of communicative approaches to second language teaching and testing. Applied linguistics, 1, 1-47. https://doi.org/10.1093/applin/I.1.1

Celce-Murcia, M. (1991). Grammar pedagogy in Second and foreign language teaching. TESOL Quarterly, 25, 459-480. https://doi.org/10.2307/3586980

Ferdinand de Saussure, (1959). Course in general linguistics. New York: Philosophical library.

Harmer, J. (1983). The practice of English language teaching. London: Longman. https://doi.org/10.1093/elt/37.2.184

Henry, B. (1957). The making of English. Macmillan and Company Limited.

Hjelmslev, L. (1953). Prolegomena to a theory of language. Baltimore: Warerly Press, Inc.

Jesperson, O. (1924). The philosophy of grammar. London: George Allen \& Unwin LTD.

Krashen, S. (1981). Second language acquisition and second language learning. Oxford: Pergamon.

Krashen, S. (1988). The Input Hypothesis: Issues and Implications. London: Longman.

Langacker, R. (2013). Essentials of cognitive grammar. Oxford: Oxford University Press.

Larsen-Freeman, D. (1991). Teaching grammar. In M. Celce-Murcia (Ed.), Teaching English as a second or foreign language ( $2^{\text {nd }}$ edition, pp. 279-295). Boston, MA: Heinle \& Heinle Publisher.

Littlewood, W. (1984). Foreign and Second Language Learning. Great Britain: Cambridge University Press.

Poutsma, H. (1928). A Grammar of Late Modern English. Groningen: P. Noordhoff.

Quirk. R. (1972). A Grammar of Contemporary English. London: Longman Group Limited.

Terrell, T. (1991). The Role of Grammar Instruction in a Communicative Approach. Modern Language Journal, 75, 52-63. https://doi.org/10.1111/j.1540-4781.1991.tb01083.x

VanPatten B. (1996). Input Processing and Grammar Instruction in Second Language Acquisition. Norwood. New Jersey: Ablex.

Weidong, D., \& Xianju, Y. (2005). Teaching Mode for Second Language Acquisition. English world, (2), 2-8.

Xiaohong, D. (2013). English Grammar Automatic Output Model under Non-native Environment Theory and Practice in Language Studies, (1), 29-34.

\section{Copyrights}

Copyright for this article is retained by the author(s), with first publication rights granted to the journal.

This is an open-access article distributed under the terms and conditions of the Creative Commons Attribution license (http://creativecommons.org/licenses/by/4.0/). 